\title{
Pszichometria Magyarországon a 20. század elsó felében
}

\begin{abstract}
VAJDA ZsUZSANNA
Károli Gáspár Református Egyetem

A modern pszichológia megszületésében - ezt a pszichológushallgatók már a bevezető kurzusokon megtanulják - alapvető szerepet játszott, hogy a 19. század derekára létrejöttek a mentális funkciók mérésének elvi és gyakorlati lehetőségei. Az egyszerúbb megismerő funkciók (érzékelés, emlékezés) mellett az értelmi képességek jelentették az első komplex emberi sajátosságot, amelynek mérésével a kutatók kísérleteztek. A koponya- és agytérfogat- vizsgálatoktól nem túlságosan hosszú út vezetett az értelem teljesítmény alapú méréséig, amelynek legsikeresebb változata a mai módszerekre is hatást gyakorló Alfred Binet nevéhez fưződik. Binet módszere gyorsan elterjedt a világ fejlettebbik felében, alig néhány éven belül Magyarországra is eljutott. Vajon tartogat-e érdekességeket a több, mint egy évszázaddal ezelőtt zajlott hazai adaptáció bemutatása a mai olvasónak? A válasz egyértelmúen igen, mégpedig több szempontból is.
\end{abstract}

A képességmérés történetének nyomon követése során láthatóvá válik a pszichológia önálló diszciplinává válásának egy fontos szakasza, az ezt követő, ma sem lezárult nyitott kérdésekkel együtt. A diszciplináris határok rögzítése különösen összetett volt a pedagógiával szemben, amelynek nemcsak a tárgya áll minden más embertudománynál közelebb a pszichológiáéhoz, hanem abban is rokon, hogy a képviselői - mint azt az intelligenciamérés meghonosítása körüli, később részletesen is ismertetendő viták is szemléltetik - szintén az „objektív tudomány" alapjaira szerették volna helyezni saját tevékenységüket.

A kor tudományfelfogása szempontjából nem kétséges, hogy az objektivitás egyik feltétele a mérhetőség. Csakhogy a képességek, mentális funkciók mérésére irányuló gyakorlati próbálkozások során egyértelmúen feltárulnak azok a nehézségek, amelyek a humán jelenségvilág kettős - környezeti és biológiai meghatározottságából fakadnak. A pszichológia korai képviselői érthető módon az információk befogadásával és feldolgozásával foglalkozó, teljesítményben is testet öltő kognitív képességek mérésére tesznek erőfeszítéseket. Ám amint többről van szó, mint a látás élességéről, vagy a reakció gyorsaságáról, már a meghatározás is nehéz. Mint látni fogjuk, a hazai és külföldi szakemberek változatos módon igyekeznek vizsgálat tárgyává tenni a gyerekek értelmi képességeit, és sokan később is szegényesnek érezték a pontozással nyert eredményeket. Fontosabbnak tartották a mérés során felfedezett tartalmi jellegzetességeket a 
gondolkodásban, amelyek mind a mai napig kívül maradnak a pszichológia látókörén.

A képességméréssel, illetve a Binet-próba meghonosításával kapcsolatos hazai erőfeszítések kapcsán megismerhetjük a korabeli nemzetközi tudományos közélet múködését. Tanulságos, hogy ezekben az évtizedekben, a világháborúk által előidézett nagy gazdasági-politikai átrendeződések előtt a mainál jóval intenzívebb kommunikáció zajlik a különböző országok, földrészek kutatói között. A párbeszédben részt vesznek a hazai szakemberek is, akik folyamatosan figyelemmel kísérik a nemzetközi tudományos élet fontosabb eseményeit. Magyarország ekkor egy európai középhatalom, az Osztrák-Magyar Monarchia egyik alkotó állama, amelyben intenzív a kapcsolattartás a központok között. A fontosabb kutatói kapcsolatok a német-osztrák központok között alakulnak ki: így például a szaksajtó beszámolói szerint a képességmérés alapjainak lerakásában fontos szerepet játszó William Stern az első világháborút megelőzően többször is jár Magyarországon. 1914-ben nagy hatású előadást tartott a Pedagógiai Szemináriumban. ${ }^{1}$ Éltes Mátyás pályája kezdetén Svájcban, Ausztriában és Németországban tanulmányozza a gyógypedagógiai oktatást (Gordosné, 1991). Nagy László rendszeresen tájékoztatja a hazai közönséget a Németországban zajló szakmai vitákról (Nagy, 1906). A nemzetközi tudományos közéletbe való bekapcsolódást elősegíti, hogy a népesség jelentős része, különösen az értelmiség, kétnyelvû, így az Európában legnagyobb, német nyelvi közösség része. Ugyanakkor egyre többen figyelnek az ebben az időben még szintén intenzív német kapcsolatokat ápoló, ám saját szemléletüket létrehozó amerikai szakemberek kezdeményezéseire.

A mérések konkrét lebonyolításának ismertetése ezen túl bepillantást enged az értelmi képességek eredetével, formálhatóságával kapcsolatos felfogásba, a mindennapi élet és múveltség néhány korabeli jellegzetességébe.

\section{Pszichológia ÉS Pedagógia MagyarorszÁgon a 20. SZÁzAd KEZDETÉN}

A pedagógia és a pszichológia diszciplináris határainak kialakulása szempontjából feltétlenül említésre méltó körülmény a mindkettőt ${ }^{2}$ magában foglaló gyermektanulmányi szemlélet térhódítása a 19. század kezdetétől a 20. század derekáig. A gyermektanulmányozás eredetéről, megjelenéséről, tárgyáról több féle interpretációt olvashatunk, de az nem kétséges, hogy rendkívül népszerû, részben tudományos, részben a gyerekek különleges sajátosságaira, ezek megismerésére és tekintetbe vételére felhívó közéleti mozgalom volt.

A mai neveléstörténeti munkák általában Stanley Hall-nak tulajdonítják a gyermektanulmányi mozgalom elindítását. Más álláspontot képvisel a ha-

\footnotetext{
${ }^{1}$ Néptanítók Lapja, 1914. 4. sz.

${ }^{2}$ Legalábbis a pszichológia gyerekkori fejlődéssel foglalkozó területeit.
} 
zai gyermektanulmányi mozgalom történetét tanulmányozó Deák Gábor, aki szélesebben értelmezve a gyermektanulmányi szemléletet - Meumann-nak és Claparede-nek tulajdonít döntő szerepet. Deák azonban ebbe a körbe von más, a gyerekkori fejlődéssel kapcsolatos munkákat is (Deák, 2000). Ez azért félrevezető némileg, mert a gyermektanulmányi szemlélet az amerikai hagyományoknak megfelelően a tudományos megismerés természettudományos módszereit, a mérés és a kísérlet alkalmazását tartja a leginkább megfelelőnek, míg hazai képviselői közül többen is - köztük a gyermektanulmány legjelentősebb képviselőjének tekintett Nagy László - nem feltétlen támogatója a pozitivista szemléletnek.

Nagy László 1906-ban megjelent tanulmányában arra hívja fel a figyelmet, hogy a gyermekkori sajátosságok vizsgálata tekintetében eltérés van az amerikai és a német szakemberek szemlélete között. Az amerikaiak szerint a „gyermek, mint egész" a vizsgálat tárgya, ide értve az anatómiát, a történelmi és néprajzi sajátosságokat, a "testi és lelki erők egymásra hatását”, míg a német kutatók az anatómia, az élettan, a testi fejlődés, az idegrendszeri zavarok, a történelmi és néprajzi vonatkozások kutatását átengedik az illető tudományok búvárainak. Nagy álláspontja szerint a gyermektanulmány az amerikai szemlélet elnevezése, míg a németek megközelítése inkább gyermeklélektanként aposztrofálható. Az „adatgyújtés” - empírikus módszerek alkalmazása - tekintetében ugyanakkor az amerikaiak szigorúbbak, mint a németek (Nagy, 1907. 8. o.). Bár Nagy szerint a korábbi hazai szerzők, Donner és Pethes a német irányban indultak el, az általa alapított társaság és a gyermekekkel kapcsolatos pszichológiai jellegú vizsgálatok továbbra is diszciplináktól független gyermektanulmányozásnak minősülnek a szaklapokban.

Bár a hazai szakemberek többször is aggodalmukat fejezték ki azzal kapcsolatban, hogy Magyarország késik a neveléshez kapcsolódó tudományok meghonosításával (pl. Donner, 1899), a tények szerint ez a lemaradás nem túl jelentős. Szabolcs Éva (2002) tanulmányában a gyermektanulmányi nézőpont hazai megjelenését a Kolozsvárott az 1880-90-es években tevékenykedő Felméri Lajosnak tulajdonítja. Hasonlóan vélekedik Pukánszky Béla (2001, 430. o.), szó szerint idézve Felméri álláspontját, amely szerint a nevelőknek alapos pszichológiai ismeretekkel kell rendelkezniük. Ez az időszak lényegében egybeesik a gyermektanulmányi szemlélet német és amerikai térhódításával. A XX. század fordulóját és első évtizedeit rendkívül élénk szakmai közélet jellemezte a hazai pedagógiában: szaklapok, folyóiratok egész sora jelenik meg (Deák, 2000).

A neveléstudományi diskurzusok jelentős része A Gyermek, ill. A Néptanítók Lapja címú periodikákban zajlik, a nemzetközi közélet eseményeiről a hazai szakemberek egyebek között A Jövő Útjain címú havilapból tájékozódhatnak. Ez utóbbi egy befolyásos európai reformpedagógiai mozgalom, az Új Nevelés Lígája folyóirata, amelyben a hazai pszichoanalitikusok is publikálnak (Vaja, 1995). A hazai gyermektanulmányt főurak támogatták: az 1903-ban Nagy László kezdeményezésére megalakult Gyermektanulmányi társaság elnöke Teleki Sándor 
gróf volt (Gál, 2012). A Néptanítók lapja 1906-ban megjelent tudósítása ${ }^{3}$ szerint Teleki, „az újonnan megalakult Gyermektanulmányi Társaság elnöke, a közmúvelődés és a közoktatás ügyeinek lelkes barátja" tudományos estélyt rendezett, ahova arisztokrata hölgyek - például Tisza Istvánné és Károlyi Istvánné - valamint az ismertebb szakemberek - Nagy László, Ranschburg Pál - is hivatalosak voltak. Az estélyen gróf Teleki ismertette a gyermektanulmány ügyének aktuális hazai állapotát és az újabb nevelési irányokat. Figyelemre méltó, hogy a tudományt pártoló fóúr a természettudományos szemléletet tekinti a modern neveléskutatás alapjának. Ranschburg Pál előadását az ismertetés szerint a közönség feszült figyelemmel hallgatta, ezt követően a kérdésről élénk eszmecsere alakult ki.

A képességmérés megfelelő módszerének kidolgozása nemcsak tudományos cél volt, hanem gyakorlati igény is. A 19-20. század fordulójára a tankötelezettségnek Magyarországon is egyre szélesebb körben sikerül érvényt szerezni. Már az 1848-as szabadságharcnak is fontos törekvései közé tartozott a közoktatás, nem utolsó sorban a magyar nyelven való múvelődés támogatása érdekében. ${ }^{4}$ Az iskolai tanulás általánossá válása más országokéhoz hasonlóan a hazai oktatáspolitikát is szembesítette azzal a ténnyel, hogy a gyerekek bizonyos százaléka nem képes eleget tenni a követelményeknek. Az 1868-as törvény szerint a ",testileg, vagy szellemileg gyenge gyermekeket" a tisztiorvos felmenthette az iskolalátogatás kötelezettsége alól, és nem kellett iskolába járniuk a „taníthatatlanul tompa elméjü" gyermekeknek sem. A szakértelmiség jelentős része számára azonban nem volt elfogadható, hogy a gyengébb képességú gyerekek teljes mértékben oktatás nélkül maradjanak, annál is kevésbé, mivel nyilvánvalóan jelentős képezhetőségi különbségek voltak közöttük. A 19. század végén német mintára létrejönnek a különleges, „kisegítő” iskolák, 1907-ben pedig megnyitja kapuit a később fogalommá vált Mosonyi utcai kisegítő iskola a Ranschburg Pál irányította "Gyógypedagógiai és Pszichológiai Magyar Királyi Laboratórium”- a mai pszichológia és gyógypedagógia bölcsője - szomszédságában.

Fennállt azonban a probléma: az enyhén fogyatékos gyerekek csoportja jelentős átfedést mutatott (ahogyan ma is) a szociálisan hátrányos helyzetúek csoportjával. A szakemberek abban reménykedtek, hogy a képességmérés segítségével objektíven elkülöníthetők lesznek a környezeti okokból, szegénység, „ingerszegény környezet” miatt lemaradó gyerekek a vélhetően szervi eredetú, kevésbé fejleszthető „,valódi” fogyatékosoktól.

\footnotetext{
${ }^{3}$ A gyermektanulmány ügye egy fơúri estélyen. Néptanítók lapja, 1906. 3. 15. 16. oldal.

${ }^{4}$ Bár 1848 után az oktatásügy átmenetileg ismét osztrák irányítás alá került, a kiegyezés után egy évvel megszületett a Népoktatási Törvény, amely 6- 15 éves korig kötelezővé tette az iskolát, amely kezdetben csak a legszegényebbek, majd 1908-tól mindenki számára ingyenes volt. A törvény hatására az iskolába járó 6-12 éves gyerekek aránya a kiegyezéskori mintegy 50, után 1896-ban 73, 1913-ban pedig már az adott korosztály 93\%-a. A huszadik század első évtizedeire az írástudatlanság jelentősen csökken Magyarországon: míg 1890-ben az analfabéták aránya még közel 40\%, 1920-ra az arányuk már csak 10\% (Mészáros, Németh és Pukánszky, 1999).
} 


\section{Az INTELLIGENCIAMÉRÉS SZÜLETÉSE}

Az értelmi képességek vizsgálatának szükségessége tehát a „levegőben volt”, a sokféle próbálkozás azonban nem vitt közelebb a pontos definícióhoz. A jelek szerint a képességmérés igénye először az elmekórtanban merült fel, úttörői közé tartozott a modern elmekórtan egyik alapítója, Kraepelin is. (Kun és Szegedi, 1978). A Binet-Simon teszt hazai adaptálásában is úttörő szerepet betöltő Nagy László 1912-ban keletkezett tanulmánya is megemlíti, hogy az értelmesség feladatok segítségével történő vizsgálata korábban az elmekórtani klinikák gyakorlata volt, a "gyengeelméjûség” azonosítása érdekében. Az elmegyógyászok szerint az értelmi képességek főbb kategóriái az „észrevétel, felfogás, figyelem, emlékezet, az ítélő-kombináló képesség” volt (Nagy, 1912., 89.o.), ezeknek megfelelően intéztek kérdéseket a betegekhez. Az elmekórtanban alkalmazott feladatokat azonban nem lehetett pedagógiai célokra felhasználni. Nem bizonyult használatónak a többek között Galton által szorgalmazott koponyamérés, a kraniometria sem (Gould, 1999). ${ }^{5}$

Pethes János, az egyik első hazai gyermeklélektani tárgyú, 1901-ben megjelent könyv szerzője szerint a "gyermekmegfigyelés" terén Stanley Hall-é a vezérszerep, aki a laboratóriumi vizsgálatok meghonosításával, előadásaival lelkesíto, sőt „gyújtó" hatással volt a szakemberekre. Ugyanakkor megemlíti, hogy Németországban már korábban is zajlottak kísérletek, például Jénában, ahol egy Stoy 6 nevú pedagógus már néhány évtizeddel korábban végzett statisztikai adatgyújtést a gyerekek képességeinek vizsgálatára. Pethes aggódik, hogy a hazai tudomány el van maradva e fontos kezdeményezések tekintetében (Pethes, 1901).

Eperjessy István 1906-ban született összefoglalójában arról számol be, hogy a 19. század utolsó harmadában több európai, elsősorban német városban zajlott a gyerekek „képzeteinek” a vizsgálata. A berlini kutató, Bartholomäi ${ }^{7}$ arra az akkoriban nem különösebben meglepő megállapításra jutott, hogy a falusi és a város gyerekek ismeretvilága és szókincse nagy mértékben eltér. Tanítóik arra panaszkodtak - idézi Eperjessy - hogy a gyerekek nem ismerik iskolájuk közvetlen környezetét sem, csak a mozgó tárgyak érdeklik őket, a „nyugvó tárgyakat" nem figyelik meg. Berthold Hartman ${ }^{8}$ Annabergben végzett

\footnotetext{
${ }^{5}$ Alfred Binet a szuggesztibilitásról szóló írásában megemlíti, hogy ő is próbálkozott a koponyaméret és az értelmi képességek közötti összefüggés igazolásával, de nem járt sikerrel. Binet a kutatókat nem mindig jellemző kritikus önreflexiója folytán - felfigyelt rá, hogy maga sem elfogulatlan, amikor a mérést végzi. Észreveszi, hogy a feladataikat jól teljesítő gyerekek fejkörfogatát hajlamos nagyobbnak, a gyengébben teljesítőkét kisebbnek mérni. (Többek között ezért jut arra az elhatározásra, hogy más módszerhez kell folyamodni.) (Binet, 1900).

${ }^{6}$ Karl Wolkmar Stoy, 1815-1885, német pedagógus, Herbart pedagógiai elveinek népszerúsítője.

${ }^{7}$ Friedrich Bartholomäi (1817-1878) német herbartiánus pedagógus, Johann Friedrich Herbart követője, az ún. „Jénai Pedagógiai Szeminárium” tagja a jénai egyetemen. Szakmódszertani múveket írt matematikából, geometriából és természettanból.

${ }^{8}$ Berthold Hartmann herbartiánus pedagógus, a 19. század végén tevékenykedett. Matematika-
} 
felmérése során, amely szintén szerepel Eperjessy beszámolójában, több száz kérdés segítségével vizsgálták első- és második osztályos gyerekek ismereteit. A gyerekeknek csak egy töredéke ismerte az órát, az évszakokat valamivel többen, de a teljes sokaságnak mindössze egy ötöde, a hét napjait az 500 gyerek közül mindössze 146 tudta felsorolni. Gyenge volt a gyerekek matematikai tudásának átlaga is.

A Németországban végzett vizsgálatok alátámasztották, hogy a szülők foglalkozása és iskolázottsága nagy hatással van a gyerekek tájékozottságára, értelmi képességeire. Eperjessy azonban arra hívja fel a figyelmet, hogy az ismertetett vizsgálatok nem voltak hitelesek, mivel csoportosan végezték őket, a gyerekek nem dolgoztak önállóan, hanem egymást figyelték. Azt sem találja megfelelő megoldásnak, hogy a vizsgálatokat a gyerekek tanárai végezték.

Eperjessy idézett munkája szerint Stanley Hall 1880-ban 134 kérdéssel vizsgálta 6-7 éves gyerekek „képzettartalmát” a berlini kutató, Bartholomäi módszere alapján. ${ }^{9}$ Hall tapasztalatai szerint a lányok képzettartalma felületesebb volt, mint a fiúké, beszélő-számolóképességük is gyengébb. A gyerekek 14\%-a nem tudta, hány éves. A fiúk azt tudták inkább, hogy mit nem szabad, a lányok, hogy mit nem illik. Téves képzeteik voltak a mennydörgésről - Hall egyik beszámolója szerint azt hitték, hogy ilyenkor az angyalok a mennyországban kugliznak.

Nagy László (1912) Ebbinghaust nevezi meg, mint a pszichometria gyerekkori alkalmazásának úttörőjét. Módszere a kombináló módszer volt - például olyan szöveget adott a tanulóknak, amelyből szótagok, vagy egész szavak kimaradtak, ezeket a vizsgált gyerekeknek pótolni kellett. Ebbinghaus pontszámok segítségével rangsorolta a teljesítményeket. Nagy megemlíti, hogy az angol Spearman, a "g faktor" fogalmának megalkotója szintén pontozta a gyerekek teljesítményét az általa kidolgozott feladatokban, majd a pontszámok alapján képzett csoportokat a pedagógusok rangsorával hasonlította össze. Ha a kétféle sorrend között nagy volt a különbség, akkor módosította a feladatokat, ha viszont közel voltak egymáshoz, akkor érvényesnek tartotta az eredményt.

Spearman módszerének az volt a legfőbb hibája - véli Nagy -, hogy a gyerekek teljesítményét az adott alkalmi csoporton belül vizsgálta, nem volt általános minta, amihez a teljesítményeket viszonyították volna. Lendületet adott a gyerekek vizsgálatának, hogy az egyetemeken, különösen Amerikában, egyre több helyen végeztek lélektani kísérleteket - ezek nyomán keletkeztek a próbák, avagy angol megnevezésük szerint tesztek. Ezekben azonban az intelligencia vizsgálata nem mint cél, hanem mint mellékes eredmény szerepelt - összegzi Nagy.

módszertani múvek szerzője, a gyermeki gondolkodás sajátosságairól a „gondolatkörökről” (Gedankenkreis) is publikált.

${ }^{9} \mathrm{Az}$ itt idézett szerző́k tanúsága szerint legalábbis pontatlan az a Gál Anikó (2012) tanulmányában szereplő állítás, mintha a gyermekek tanulmányozásának kezdeményezője Stanley Hall lett volna. 


\section{HAZAi KÍSÉRLETEK}

Német, amerikai és francia kollégáikhoz hasonlóan a magyar szakemberek is kísérleteztek gyermekek képességeinek vizsgálatával és hasonló nehézségekkel szembesültek. Eperjessy már idézett cikkében (Eperjessy, 1906) beszámol róla, hogy Éltes Mátyás és Ranschburg Pál 6-7 éves, iskolakezdő gyermekeket vizsgáltak egy gyermekek számára készült ismeretterjesztő munka, a „Mindentudó képeskönyv" közel 1000 színes ábrájának segítségével. A gyerekeknek meg kellett mondani a képek neveit, a fel kellett sorolni a részleteket. A teljesítmények nagy eltéréseket mutattak: a legjobb válaszoló 150 főnévből 130-at ismert fel, a leggyengébb 50-et. Maga Eperjessy 1904-ben 20 hat éves gyermeket vizsgált szintén az említett képeskönyv segítségével egy kültelki iskolában. A gyerekek többsége napszámosok, szegény iparosok gyermeke volt. Itt is erősen érzékelhetô volt a társadalmi háttér hatása: egy tanító gyermeke $60 \%$-ot felismert a képeskönyvben ábrázolt tárgyak közül, míg a napszámos gyermekek átlagosan csak 17\%-et. Gyakran csacskaságokat válaszoltak, a papagájt például cédulahúzó madárként jellemezték, azt hitték, hogy az elefánt Törökországban élt és volt, aki nem ismerte fel Petőfi Sándor szobrát. Akárcsak a német vizsgálatok, a hazai kutatásokról szóló beszámolók is tükrözik, hogy a tankötelezettség kezdetén, a modern tömegkommunikációs eszközök megjelenése előtt és feltehetően a nagyon jelentős szociális különbségek hatására a mainál (is) jóval nagyobb volt az eltérés a különböző hátterú gyerekek tudása, ismeretei között.

Egy másik esetben Éltes és Ranschburg egy 7 éves, „mérsékelten gyengeelméjú kislány szó- és képzetkincsét" is megpróbálta felmérni, ugyancsak a Mindentudó Képeskönyv segítségével. A lányka "gyengeelméjûsége” elsősorban a számolási nehézségekben nyilvánult meg. Eperjessy egy 4 éves, ép értelmú fiú teljes szókincsének feltérképezésére tett kísérletet: napokat töltött a társaságában, és minden szavát feljegyezte. Megfigyelései szerint a kisfiú 6698 szót használt beszéd közben. Az anyag feldolgozása negyedévi fárasztó munkába került - jegyezte meg.

Ranschburg Pál nem tartotta meggyőzőnek a felmérések eredményeit - írja Eperjessy - ezért felkérte a gyermektanulmányi társaság kebelében alakult Pedológiai Bizottságot a vizsgálat további folytatására. Ebben szintén a „Mindentudó képeskönyvet” használták, a felmérést tanítók végezték. Kikérdezték az iskolakezdő gyermekeket otthoni körülményeikről, saját tevékenységükről, megkísérelték felmérni verbalitásukat, a színek, számok ismeretét, vizsgálták a gyerekek fizikai adottságait is. A beszámoló szerint ugyan a változó létszámú gyerekcsoportok teljesítményátlaga jobb volt egy német vizsgálatban ismertetett annabergi csoporténál, ám a teljesítményükben rendkívül nagy volt a szórás: a legjobb teljesítmény 150 főnévből 130 felismerése volt, a leggyengébbek azonban csak 50-et ismertek fel. A színek ismeretét 80 gyereknél vizsgálták, 10 alapszínt kellett felismerniük. Az átlag 7 szín felismerése volt, de a volt, aki csak hármat 
tudtak azonosítani. 210 tanulónak számokat kellett felismernie: ezt a gyerekek 86\%-a sikerrel teljesítette. A szék, olló, kanál, pipa, kutya jelentését a megkérdezett gyerekek 99\%-a ismerte, de például a fürdőkád, a szarvas, vagy a tyúk jelentését már csak $54 \%$, és $25 \%$-nál is kevesebben voltak képesek azonosítani a juh, táviró, drót, sakk, tulipán, gramofon stb. tárgyakat. Különösen szegényes volt azoknak a gyerekeknek az ismeretvilága, akik nem jártak óvodába - úgy túnik, a szülőknek nincs ideje a gyermekkel foglalkozni - állapította meg Eperjessy. Javaslatokat is megfogalmazott az értelmesség elősegítésére: ki kell vinni a gyermeket a szabad természetbe, és „minden tanulságosra” fel kell hívni a figyelmét, mert csak azok az ismeretek tartósak, amelyeket a közvetlen tapasztalat útján szerzünk. Nem helyes csupán száraz ismeretközlésre szorítkozni, gyakorlati példákkal kell megvilágítani, amit meg szeretnénk tanítani. Ugyanez vonatkozik az etikai szabályokra - legyenek képesek átélni, milyen az, ha bezárnak egy madarat a kalitkába.

A fent idézett eredmények világosan jelzik - összegzte mondanivalóját Eperjessy - hogy a tanítóknak ismerni kell a gyerekek ismeretvilágát. Aggasztotta, hogy a városi gyermekek „képzettartalma” túl nagy terjedelmú - az utóbbival kapcsolatban felmerült annak kockázata, hogy a „rohamosan összetorlódó gondolatképek nem homályosítják-e el egymást?” (Eperjessy, 1906. 134. o.).

\section{BERKOVICS RENÉ VIZSGÁlATAI}

A képességmérésekkel kapcsolatos jelentôsebb próbálkozások közé tartozott Berkovics René nagyváradi orvosé, amelyet „esettanulmányként" részletesen is ismertetünk. Berkovics (Berkovics, 1913). a hazai szerzők közül elsőként használta az intelligencia kifejezést, ám megállapította, hogy mindenki mást ért alatta. Ez nem meglepő - szögezi le - hiszen aligha rendelkezünk a normális intelligencia pontos kritériumával, amelynek alapján úgy mérhetnénk az értelmességet, mint a méterrúddal a hosszúságot.

Berkovits egy 66 kérdésből álló sorozatot állított össze, amelyet az orvosi gyakorlatban és az oktatásban tervezett alkalmazni. Azokat tekintette normál intelligenciájúaknak, akik az általa kidolgozott feladatok több, mint a 90\%-át meg tudták oldani. A tesztet felnőttek számára készítette, ezért üdvözölte Binet és Simon próbálkozását az intelligencia „lépcsőzetes” mértékének meghatározására. Fontos lenne - jegyezte meg - hogy a gyerekek intelligenciáját meg tudjuk becsülni, ehhez azonban arra van szükség, hogy ismerjük életkori sajátosságaikat. Vannak gyerekek, akik az „ú.n. játékos korban” értelmesnek látszanak, de már az elemi oktatás első lépéseinél megakadnak. Az orvosi vizsgálat nem talál szembeötlő defektusokat, az otthoni miliő sincs a gyerek ártalmára, mégis elmarad a többitől. Ma már általános az a nézet, hogy az ilyen, gyengébb képességú gyerekeknek kisegítő iskolába kell járnia. Ennek érdekében objektív mércére van szükség - szögezte le -, mivel kételkedik benne, hogy a 
pedagógusok értékítéletei mindig helytállóak-e a gyerekek fogyatékosságával kapcsolatban. Ha erről egy vizsgálattal képet kaphatnánk, a gyerekeket számtalan kellemetlen helyzettől, a pedagógusokat pedig sok felesleges munkától kímélnénk meg - vélte.

Berkovics végül iskolakezdő gyerekek számára is kidolgoz egy feladatsort, amelyet a Binet-teszt életkori táblázatai szerint épít fel. A vizsgálatot nagy gonddal végezte: előzetesen több próba-mérést tartott, hogy a kikristályosodjon a megfelelő kérdezési mód, megismerje a gyerekek várható reakcióit. A minta összeállításához elemi iskolai tanítók segítségét kérte, így választottak ki 40 átlagos képességû 6-7, ill. 40 feltételezhetően enyhén fogyatékos 6-9 éves gyereket. (Az életkori eltérés abból adódott, hogy az enyhén értelmi fogyatékosok még 8-9 éves korukban is az első osztályba jártak).

A kérdések között szerepelt mindennapi tárgyak felismerése , az ezekre adott válaszok azonban félrevivőek voltak, hiszen jelentős különbség volt a gyerekek teljesítményében annak a függvényében, milyen volt a nevelői környezet. Más feladatok megoldása arra hívta fel a figyelmet, hogy gondolkodás vizsgálatánál a tartalmi szempontok sem elhanyagolhatóak. Így például, amikor a gyerekeknek példát kellett mondania négy, illetve kétlábú állatokra, Berkovits azt tapasztalta, hogy az enyhén értelmi fogyatékos gyerekek közül jóval kevesebben voltak, akik kétlábú állatot meg tudtak nevezni. Feltételezte, hogy számukra az „állat” képe - ma kognitív sémának neveznénk - elsősorban négylábú. Az 1911-ben első osztályba járók közül senki sem tudott választ adni a kérdésre, mennyibe kerül a zsemle. Berkovics magyarázata szerint a gazdag gyerekek soha nincsenek jelen vásárlásnál, a szegényeknek pedig nincs dolga pénzzel. Azt is csak a gyerekek töredéke tudta, hogy hívják az ország királyát, holott a Monarchia császára és Magyarország királya ekkor már több, mint fél évszázada Ferenc József volt. Az egyébként ép értelmúnek bizonyult gyerekeknek is csupán a háromnegyede tudta megfogalmazni, mi a különbség a szék és az asztal között. A színeket az ép értelmú hat évesek biztonsággal felismerték, az enyhén értelmi fogyatékosok azonban nem. ${ }^{10}$

Berkovits megállapítása szerint a tartalmi különbségek vizsgálata alkalmasabb lenne a fogyatékosok és az átlagot elérők elkülönítésére, mint maga a pontszám. Mint látni fogjuk, más, a képességméréssel foglalkozó hazai kutatók hasonló következtetésre jutottak, ám különböző okokból mégis szinte kizárólag a számszerú, tartalomtól független statisztikai alapú mérések terjedtek el a tudományban és a gyakorlatban.

\section{MIÉRT ÉPPEN BINET?}

Áttekintve a korabeli próbálkozásokat felmerül a kérdés: mi a magyarázata, hogy a sokféle hasonló kísérlet közül éppen Binet és Simon módszere vált elfogadottá

\footnotetext{
${ }^{10} \mathrm{Ma}$ a színek felismerése 3-4 éves kori sztenderd.
} 
és sok későbbi intelligenciateszt alapjává? Nagy László (1912) rávilágít az egyik legfontosabb okra: a teljesítmények és az életkor kapcsolatának felismerése által létrejött az a viszonyítási alap, amelynek hiánya megnehezítette a korábbi mérések értelmezését. A gyermekkori képességek felső határa, az a szint, amelytől fogva az idősebb gyermekek teljesítménye már nem javult jelentősen, elvileg elvezetett a felnőtti sztenderd rögzítéséhez.

Binet eljárásának másik, követendőnek bizonyult eljárása a feladatok változatos karaktere: Néhány példa Alfred Binet eredeti próbáiból (Éltes, 1914b. 9. o.)

3 év: Megmutatja orrát, szemét, száját, stb., két számot ismétel. Felsorolni egy kép személyeit, vagy tárgyait. Megmondani családnevét. A képen levő tárgyakat megnevezi, 6 szótagból álló mondatot ismétel.

4 év: Megmondani, hogy fiú, vagy lány-e. Megnevezi (megmutatja) a kulcsot, a kést, egy fillért stb, megismétel három számot. 5 és $6 \mathrm{~cm}$ hosszú vonalat összehasonlít.

5 év: Az egyformának látszó két 6 és 12 gr, továbbá 6 és 15 gr-os skatulyát összehasonlít, megmondja, melyik a nehezebb. Tíz szótagból álló mondatot elismétel, türelemjátékot megfejt. (Két téglalap közül az egyiket átlósan kettévágjuk és a gyermeknek össze kell úgy illesztenie, hogy téglalap legyen).

Könnyen belátható, hogy a feladatsor más, komplexebb értelmesség- definíciót sugall, mint az ismertetett német és hazai vizsgálatok. Az utóbbiak, mint arra korábban utaltunk, általában kiválasztottak valamilyen jól- rosszul definiált kognitív képességet: a „gyermek képzettartalmát”, a szókincset, a tájékozottságot, a számolási képességet stb. A Binet-próba ezzel szemben többféle képességet (emlékezet, logikai képesség) és a cselekvésben megnyilvánuló értelmességet is vizsgálja, az ezekben nyújtott teljesítmények átlagából alakul ki az értelmesség életkori kvóciense. Ebben követi a ma is a legalaposabbnak tekintett Wechsler-sorozat, amelynek első változatát a névadó kutató dolgozta ki az Egyesült Államokban az 1930-as években. Vagyis a Binet-próba latens intelligenciafogalma valóban nem egy-egy kognitív képesség színvonalát méri, hanem olyan képességet, amely eltérő karakterû feladatokban hasonló szinten jelen van - kimondatlanul előfeltételezve a Spearman által bevezetett "g" faktor létét (Pléh, 2000).

Fontos megjegyezni, hogy Binet nem értékeli túl az általa kidolgozott vizsgálatot: több írásában is kiemeli, hogy a módszere nem mindenható. A mérést nem végezheti bárki: „Nem kezelési módszer és a sietős orvosnak, ki az ápolókkal akarná alkalmaztatni, megjósoljuk, hogy meg fogja bánni." (Binet, 1916. 120. o.). Az eredményeket kommentálni és értelmezni szükséges - hívja fel a figyelmet. Álláspontja szerint a vizsgálat pontossága csak annyi, „amennyi a lelki jelenségekkel összefér; a képzettségi fokot nem lehet olyan pontosan megmérni, mint a test súlyát, vagy magasságát. A gyermek figyelme, emlékezete, lélekjelenléte, mind törékeny tulajdonságok, amelyek nem jelentkeznek mindig ugyanabban 
az állapotban; egyik nap tíz hibát ejt egy tollbamondásban, másnap húszat fog elkövetni ugyanolyan körülmények között. A vizsgálatnak tehát nem célja, nem is lehet célja kijegecesíteni egy gyermeket; a gyermek változó marad, mint a természete kívánja" (Binet, 1916. 34. o.).

Binet arra is nyomatékosan felhívja a figyelmet, hogy az iskolai balsikerek oka változó. Véleménye szerint legalább száz „,szekundást' kell megvizsgálnunk, hogy felismerjük mindazokat az okokat, amelyek a gyengébb teljesítmény magyarázatául szolgálhatnak A felsorolt okok közé tartozik, hogy a család gyakran anyagi körülményei miatt nem múködik együtt kellőképpen az iskolával. Binet szerint a gyerekek külseje és viselkedése is elárulja, hogy le vannak maradva. Az összbenyomás - a testtartás, az arcszín és az arcvonások - elárulják, ki az, aki fogyatékossággal küzd. Binet fiziológiai nyomornak nevezi ezeknek a gyerekeknek az állapotát, amely társadalmi nyomorból ered. Meggyőződése szerint azonban az értelem „minden érzékenységi, érzelmi és akarati jelenségtől független” megismerő képesség (Binet, 1916. 111. o.). Fontosnak tartja kiemelni, hogy az értelem fejleszthetô. A túlságosan nehéz feladat elkedvetlenít - szögezi le -, lehetőleg ne kívánjunk többet a gyerekektől, mint amire valóban képesek.

\section{A Binet-PRóbA HAZAi ADAPTÁciója}

A képességmérés rendszeres használatához szükséges hazai sztenderd kidolgozását végül a gyógypedagógia úttörője, Éltes Mátyás végezte el. ${ }^{11}$ Éltes gyakorló pedagógusként is foglalkozott a fogyatékos gyermekekkel, és tapasztalatai alapján feltétlenül szükségesnek látta olyan eszköz kidolgozását, amelynek segítségével objektíven és biztonságosan meg lehet húzni a határvonalat a normalitás és a fogyatékosság között. Binet-től eltérően úgy vélte, hogy a „gyengeelméjűségnek" nincsenek külső jelei. Előfordul ugyan, hogy a fogyatékosság valamilyen testi, vagy nyilvánvaló agyi rendellenességgel függ össze, de egyáltalán nem mindig. Gyakori, hogy a gyengeelméjû egyénen semmilyen kóros elváltozást nem találunk - írta (Éltes, 1902).

1914-ben a Magyar Gyermektanulmányi Társaság ülésén hangzott el Éltes beszámolója a Binet-teszt adaptációjáról. 1911-ben kezdte el Binet próbáit magyar nyelvre fordítani, Nagy László már meglévő fordításának felhasználásával és a gyöngetehetségú gyerekek kiválasztására alkalmazni. Csakhamar kiderült, hogy a próbák abban a sorrendben, ahogyan Binet alkalmazta, a hazai felhasználáshoz nem felelnek meg. Éltes szerint először az átlagos képességú gyerekek teljesítményéről kellett képet kapni, csak ennek alapján vizsgálhatók a lemaradást mutató gyerekek.

\footnotetext{
${ }^{11}$ Éltes pályája kezdetén német, osztrák és svájci intézetek egész sorát látogatta végig, mivel alaposan szeretett volna tájékozódni a fogyatékosság, vagy ahogyan akkor nevezték, a gyengeelméjúség megítélésének, kezelésének kérdéseiben. Csalódottan állapítja meg, hogy sem a gyengeelméjúség lényegére, sem annak általános érvénnyel bíró okaira nézve nem találkozott határozott állásfoglalással.
} 
Saját vizsgálatát budapesti, 8. kerületi iskolákban végezte, az 1911-es próbákkal. A nemzetközi tesztet alkalmazta, mert ekkori reményei szerint így a mi eredményeinket összevethetjük a „múvelt nemzetek gyermekein” végzett kutatások eredményeivel. Az intelligencia definíciójánál W. Stern definícióját fogadta el: az egyének általános képessége, amellyel a gondolkodását tudatosan új irányba fordítja, általános lelki alkalmazkodóképesség az élet új feladataival szemben. "Az intelligenciát magyarul értelmességnek nevezhetnénk és nem azonos a lángésszel, sem a talentummal, sem az iskolai tudással." - állapítja meg (Éltes, 1914. 258. о.).

A tesztet 40 3-5 és 178 6-12 éves gyerekekkel végezte Budapest munkások és az alsó középosztály által lakott kerületeiben. Elsősorban a német adaptáció eredményeire, Bobertag, Chotzen és Stern munkáira támaszkodott. Az új próbákat az említetteken kívül még 438 gyermeken próbálta ki. (Éltes, 1914; Gál, 2012). A német adaptálókhoz hasonlóan Éltes is szembesült azzal, hogy a hasonló korú magyar és a francia gyerekek nem ugyanazokat a feladatokat tudták megoldani. Mások a pénznemek, de a „francia gyermek lelkében bizonyos egyéni sajátosságok máskép alakulnak ki, mint a magyar gyermeknél" (Éltes, 1914. 259.) - írta. Néhány érdekes példa: a két háromszögből téglalap összeállítása az 5 éves francia gyerekek számára egyáltalán nem okozott gondot, a magyar ötéveseknek azonban csak 5\%-a, a hatévesek $48 \%$-a és még a hétéveseknek is csak $68 \%$-a oldotta meg. Hasonló eltérés volt a rombusz (korabeli szóval dülény) másolásánál: Binet szerint ez 6 éves korúaknak való feladat, ám a magyar 6 éveseknek csak 28\%-a, a 7 éveseknek is csak a 64\%-a birkózott meg vele. A fiúk ebben a feladatban sokkal jobbak voltak, mint a lányok: a 7 évesek $85 \%$-a, az ugyanilyen korú lányoknak azonban csak a $42 \%$-a volt képes a rombusz lerajzolására. Éltes több területen is tapasztalta, hogy a fiúk és a lányok teljesítménye eltér, voltak próbák, amelyekben a fiúk és voltak, amelyekben a lányok bizonyultak ügyesebbnek. A fiúk és a lányok teljesítményében mutatkozó különbség oka feltehetően összefüggött az iskolázottság jellegzetességeivel (a tankötelezettség nem egyformán terjedt ki a fiúkra és a lányokra és nem is egységes tanterv szerint tanultak), mivel a mai mérések szerint nincsenek szignifikáns különbségek a fiúk és a lányok teljesítménye között (Vajda, 2017).

A magyar és a francia gyerekek eredményei közötti különbségek miatt az átlagok egészen máshol helyezkedtek volna el, ezért Éltes úgy alakította át a Binet-Simon-féle tesztet, hogy az jobban illeszkedjen az itthoni gyerekek teljesítményeihez. Eközben igyekezett kiküszöbölni Binet néhány pontatlanságát. Például Binet nem határozta meg egyértelmúen, hogy a nem teljesítők milyen arányánál kell az adott feladatot az idősebbekéhez sorolni. Éltes ezt az arányt az adott korosztály 55\%-ában állapította meg. Ugyanakkor nem követte Bobertagot, aki teljesen átalakította Binet 10-15 évesek számára javasolt próbáit. Éltes verziójában a pontozás súlyozása is alakította az eredményt, mivel álláspontja szerint 11-15 éves korban az értelmi fejlődés lelassul. 
A teszt adaptált formájával végzett mérés szerint az ép magyar gyermekek nagy átlagának értelmi fejlettsége megfelelt az életkoruknak: a 302 vizsgált gyerekből 203 esetében az intelligenciakor(IK) és az életkor (ÉK) közel volt egymáshoz. Ez azért fontos - szögezte le Éltes - mert, ha a gyerek teljesítménye nem felel meg a korának, akkor a pedagógus nem tud objektíven értékelni. A vizsgálat lehetősége befolyásolja az oktatáspolitikai döntéseket is, mivel az eredmények alapján a gyerekek kb. 20\%-a 6 éves korában még nem éri el az életkornak megfelelő értelmességi fokot. Az ő esetükben a beiskolázást későbbre kellene halasztani. A másik 20\% a zseniális gyerekek, ezekról ugyanúgy kellene gondoskodni, mint a vakokról és siketekről - vélte. A 11-12 éves korosztály feltûnően gyengének bizonyult a próbákban: Éltes szerint az ok az volt, hogy a felmérést elemi iskolásokkal végezte, a jobb képességú gyerekek viszont általában 10 éves koruk után középiskolában folytatták a tanulmányaikat. Kiegészítésképpen egy alsó fokú középiskolában is elvégezte a mérést, itt valamivel kedvezőbbek voltak az eredmények (Éltes, 1914).

\section{VITA A HAZAI ADAPTÁCIÓ EREDMÉNYEI KÖRÜL}

Éltes beszámolója után vita alakult ki az ülésen. A hozzászólók egy része határozottan ellenezte az eredeti, Binet-ék által kidolgozott próbák megváltoztatását, véleményük szerint a tesztet eredeti formájában kellett volna alkalmazni. A változtatásokkal - érveltek a hozzászólók - elvész a nemzetközi összehasonlítás lehetősége. Révész Géza (ekkor a Pedagógiai Szeminárium keretében múködő Lélektani Laboratórium igazgatója) is vitathatónak tartotta az egyes feladatok más korosztályokhoz történő átültetését. Véleménye szerint, ha komoly eltérések vannak a különböző országok gyerekei között, akkor a teszt szorul korrekcióra. Amellett érvelt, hogy az intelligenciatesztet univerzálissá kell alakítani.

Csakhogy számos jel utalt rá: a Binet-Simon-tesztben nyújtott teljesítmények nem feltétlenül kapcsolhatók össze az értelmi fejlődés univerzális sajátosságaival, vélte Révész Géza tanítványa, névrokona, a szintén a Lélektani Laboratórium munkatársaként tevékenykedő Révész Emil. Mint arról már szó esett, ő is végzett kísérleteket a Binet-Simon teszt hazai kipróbálására, mégpedig jóval nagyobb, 700 fős mintán. Vizsgálatában (amelynek dokumentumai nem lelhetőek fel) a 7 éves magyar gyerekek gyengébbek, a 8 évesek pedig jobbak voltak, mint a franciák. Révész Emil szerint a Binet-Simon-próbák általában túlságosan könnyứek voltak, és minden korosztálynál találkozhatunk olyan kérdésekkel, amelyek a változó tárgyi tudást vizsgálták, ezért a Binet-Simon-teszt nem alkalmas az általános értelmesség mérésére.

A vitát végül a nagy tekintélyú Nagy László döntötte el. Nem értett egyet az összes „múvelt nemzetre” kiterjedő egyetemes érvényú teszt alkalmazásával, helyeselte, hogy a próbákat Éltes a magyar gyerekek sajátosságaihoz igazította. Felhívja a figyelmet, hogy a Binet-Simon tesztnek elsősorban gyakorlati jelen- 
tősége van: például a beiskolázásnál vagy a fiatalkorúak búncselekményeinek jogi megítélésnél. Az átlagos, a gyengébb és a tehetséges gyerekek aránya az Éltes-próba alapján megfelelt a Binet-Simon, és a teszt német adaptálója, Bobertag vizsgálati eredményeinek, tehát a módszer jó. Mindemellett látható, hogy az eltérő környezetben nevelkedő - például a falusi és a városi - gyerekek teljesítménye nagyon különböző, ezért lehetséges, hogy a vizsgálatukat is eltérő módszerekkel kellene végezni.

A másik hozzászóló a szintén köztiszteletnek örvendő Ranschburg Pál volt. Szerinte érthető az igény olyan módszer kidolgozására, amely a tiszta intelligenciát vizsgálja, és amely fundamentális és abszolút, ám látni kell, hogy erre még nincs lehetőség. A „fundamentális” vagyis univerzális alaptulajdonságok mérésére a pszichológia egyelőre nem rendelkezik eszközökkel - vélte. "Az egész pszichológia összes kérdéseinek minden apró tényrészletükben vitán felül tisztázottaknak kellene lenniök", ehhez pedig - írta Ranschburg - az egész jelen század is kevés idő lesz. Ő is állást foglalt amellett, hogy az intelligenciavizsgálat gyakorlati kérdés. Megnyugtatónak tartotta, hogy a Binet-Simon-teszt nem az iskolai teljesítményt vizsgálja, hanem attól elkülöníthető képességet, és megfelelőnek tartja, hogy a Binet-Simon teszt nem izolált, hanem összetett képességeket próbál mérni (Éltes, 1914. 269. o.).

Éltes válaszában szintén kiemelte, hogy Binet nem egyes képességeket akart vizsgálni, hanem a lelki képességek egész komplexumát, ezért a feladatok áthelyezése nem ellentétes a tesztalkotó szándékával. Binet maga sem ellenezte ezt az eljárást és mások is alkalmazták - hívja fel a figyelmet. Ha a feladatokat nem adaptáljuk a hazai gyerekek képességeihez, akkor éppen a végeredmény, az átlag lesz irreális, ami szintén lehetetlenné teszi a más nemzetek eredményeivel való összehasonlítást. Mivel Révész Emil azt is kifogásolta, hogy nem a jó képességû́ gyerekeket vizsgálta, elmondta, hogy ezúttal a „legnagyobb számú" az átlagot képviselő szociális néposztály gyermekein akarta kipróbálni a tesztet. Bizonyos benne hogy a Belvárosban a jó nevelésben-oktatásban részesült tehetséges gyerekek jobb eredményeket érnek el, mint az erdélyi havasok pásztorgyermekei. Ám meggyőződése szerint a különbségek 8-9 éves korban eltûnnek, vagy minimálisra redukálódnak: az iskola vagy az élet megszünteti őket $^{12}$ (Éltes, 1914).

\footnotetext{
12 Nagy (1912) egy korábbi tanulmányában is kifejti, hogy a múvelt szülők és a „köznép” gyermekei közötti különbség elsősorban kisebb korban, 3-6 éves korban mutatkozik, ekkor a gyermekek fizikai életkora mögött az értelmi képességei 2-3 évvel visszamaradnak, ám a kedvező társadalmi helyzetú, mûvelt szülők gyermekeinek értelmi előnye a nem múvelt szülők gyermekei fölött fokozatosan csökken. Ebből arra lehet következtetni, hogy a jobb módú és múveltebb szülők gyerekeinek „jjobb kilátásai az életben való boldogulásra nem a tehetségükön alapul, hanem azon, hogy könnyebben bejutnak magasabb iskolákba". Sajnos, nem tudjuk, hogy Nagy vajon konkrét adatokból, vagy egyedi tapasztalatokból szû́rte-e le a véleményét, pedig nem kis jelentősége volna, ha lehetőség volna a korabeli és a későbbi, iskolázottsággal kapcsolatos társadalmi mobilitás vizsgálatára.
} 


\section{Az INTELLIGENCIAMÉRÉS ALKALMAZÁSA A BEISKOLÁZÁSNÁL}

A Binet-Simon teszt adaptációja tehát valóban segítséget jelentett a különleges oktatást igénylő, gyengébb képességú gyermekek azonosításában. ${ }^{13}$ Éltes azonban a mérés hasznosságának hangsúlyozása mellett arra hívja fel a figyelmet, hogy „,a módszer a lélektani kísérletezésben nagy jártasságot, finom megfigyelőképességet és szigorú önbírálatot kíván a vizsgálótól” (Éltes, 1916. 317. o.). A világháború megrázkódtatásai közepette sem hagy fel törekvésével, hogy a pedagógusokat meggyőzze az intelligenciamérés fontosságáról. A gyógypedagógia, a gyermekbíróságok tevékenysége, a javító nevelés a gyermek alapos megismerésén kell, hogy alapuljon - hívja fel a figyelmet. Ezen túl az intelligenciamérés segítségével elkerülhető, hogy olyan gyerekek kerüljenek kisegítő iskolába, akiknek az elmaradása látszólagos és nincs szükségük különleges bánásmódra. Sem a társadalomnak, sem a gyermeknek nem érdeke hogy az ilyen gyerekek különleges iskolába járjanak. Ugyanakkor azt is fontosnak tartja, hogy a gyerekek megítélése ne csak az intelligenciamérés alapján történjék, hanem folyamatos megfigyelések alapján szülessenek a gyerekek sorsát érintő fontosabb döntések. Javaslatára a kisegítő iskolák tanítói és orvosai ún. minősítő lapot vezetnek, amelyen folyamatosan feljegyzéseket készítenek a "gyönge tehetségú" tanulókról. Az intelligencia mérése mellett alapos anamnézist vesznek fel, tájékozódnak a gyerekek családi életéről, szociális hátteréről (Éltes, 1915; Gál, 2012).

A képességméréssel foglalkozó szakemberek sikerének tudható be, hogy az 1921-es oktatási törvény kimondja a fogyatékos gyermekek tankötelezettségét. Beiskolázásukat ugyanakkor akadályozza, hogy nem jön létre a kisegítő iskolák országos hálózata, Budapesten kívül mindössze öt, a fogyatékos gyermekeket oktató iskola létesül. A szakemberek körében növekvő csalódottságot okoz, hogy az oktatási kormányzat elsősorban anyagi okokból hátráltatja újabb kisegítő iskolák létesítését (Éltes, 1928).

Igaz, már ebben az időben is vannak, akik nem értenek egyet a fogyatékos gyerekek külön oktatásával. Csillag Lipót 1918-ban megjelent cikkében arról ír, hogy egy fővárosi iskolában a szülők kezdeményezték a gyerekek képességek szerint osztályokban tanítását. Csillag ellenzi a szegregációt mind a tehetséges, mind a gyengébb képességú gyerekek esetében. Kiemeli az iskola nevelő funkcióját, amelybe beletartozik, hogy a különböző képességú gyerekek együttmúködjenek: a tehetségesek ne gúnyolják és vessék meg gyengébb társaikat, a gyengébbek pedig irigység helyett értékeljék és igyekezzenek utánozni a jobbakat. Nem jó, ha az iskolában el vannak különítve, hiszen az életben úgyis

\footnotetext{
${ }^{13}$ Bár kétségkívül ez volt az alkalmazók törekvése, nem állja meg a helyét Gál Anikó megjegyzése, amely szerint az adaptált Binet-próba alkalmas lett volna a szociális helyzetük, illetve idegrendszeri károsodásuk miatt lemaradók egyértelmú megkülönböztetésére. Az utóbbit gyakorlatilag lehetetlenné teszi, hogy a súlyos nyomor és nélkülözés az élet első éveiben hátráltatja az idegrendszer fejlődését és szervi szintû elváltozásokat is okozhat.
} 
találkozniuk kell. A tehetség egyébként is ritkán homogén: vannak gyerekek, akik bizonyos tárgyakban tehetségesek, másokban nem. Az értelmi fogyatékos gyermekeket álláspontja szerint csak átmenetileg szabad külön nevelni, lehetőleg vissza kell juttatni az egészségesek közé. Összességében tehát nagy hiba már az általános iskolában elkülöníteni a gyerekeket - az osztálynak együtt kell leküzdeni a nehézségeket - állapítja meg (Csillag, 1918).

Úgy tû́nik, hogy a kisegítő iskolai rendszert Éltes sem találja minden szempontból megnyugtatónak: 1928-ban írott tanulmányában egy német modell átvételét javasolja, amelynek megfelelően a gyengébb képességú gyerekeket egy éven át normál tantervú, de kis létszámú osztályban tanították. Itt nem volt osztályzás, csak megfigyelték a gyerekek haladását, és csak ezt követően dőlt el, milyen iskolatípusba kerüljön. Így elkerülhető a „szekunda”, a gyerek rossz osztályzattal való megszégyenítése (Éltes, 1928).

\section{PSZICHOMETRIA A HAZAI PSZICHOLÓGIÁBAN A KÉT VILÁGHÁBORÚ KÖZÖTT}

Miközben az Egyesült Államokban az intelligenciamérés a diadalútját járja olyan érzékeny politikai területekhez kapcsolódva, mint a bevándorlók szelekciója (Gould, 1999), a hazai szakembereket továbbra is intenzíven foglalkoztatják a pszichometria nyitott kérdései. Nem született meg az intelligencia egyértelmú definíciója, a kutatók minduntalan szembesülnek vele, hogy az értelmi képességek kvantifikálása távolról sem tükrözi sem a funkció összetettségét, sem az egyéni különbségeket. Maga Nagy László sem vált a képességmérés feltétel nélküli támogatójává. 1925-ben történő kényszernyugdíjazása után szerepet vállal a Pedagógia Szeminárium Lélektani Laboratóriumában, ahol új kategóriát dolgoznak ki a gyerekek értelmi képességeinek vizsgálatára: a pszichogrammát. Álláspontja szerint az utóbbi „nem lehet a lélektani tények száraz összefoglalása.... összeállítása nem lehet pusztán a pszichológiai tudás eredménye. Annak alkotó elemei között az intuíció is helyet kell hogy foglaljon. A jó pszichológusnak nemcsak tudósnak, hanem múvésznek is kell lennie." (Nagy, 1926. 98. o.).

Focher László és Szondi Lipót 1919-ben adják közre saját pszichometriai vizsgálatuk eredményeit, amelyek a mentális teljesítmények szociális meghatározottságára hívják fel a figyelmet. A vizsgált minta tagjai „falusi iskolát végzett egyének - normális iskolásgyermekek és legénységi állományú katonák". A szerzők megállapítják, hogy a koponyaméretek és a mentális teljesítmény között nincs összefüggés. Adataik szerint a falusi iskolát végzettek teljesítménye valamennyi feladatban nagyobb szórást mutat, mint a városiaké, emellett a városiak 100\% körüli teljesítményével szemben a falusiak gyakran csak 60-70\%-os teljesítményt érnek el. Megállapításaik szerint a szavakra való emlékezés és a huszas számkörben való számolás mutatja a legmagasabb korrelációt más teljesítmé- 
nyekkel, tehát ez a két próba alkalmas az intelligencia általános megítélésére. Az idősebb kor - állapítják meg - befolyásolja a százalékos eloszlást, a normalitás határán kívül eső kivételek ritkábbá válnak. (Focher és Szondy, 1919. 199.o)

Hosszabb tanulmányt szentel a tesztvizsgálatok értékelésének Hermann Imre is, akit a pszichoanalízis mellett egész pályáján intenzíven foglalkoztatott a racionális gondolkodás, az értelmi képességek kérdése. Kétségbe vonja, hogy egy vizsgálat, bizonyos feladatok megfejtése alkalmas-e rá, hogy általa megismerjük a gyermek „lelki sajátosságait”. Álláspontja szerint minden teszt „Janus arcú" - más a vizsgáló és más a vizsgált személy szempontjából. William Sternt idézi, aki szerint tesztekkel olyan tulajdonságok vizsgálhatóak, amelyek viszonylag állandóak és amelyek elemi - nem összetett - jelenségek. Márpedig az „állandóság követelése kizárja a szerzett tudás vizsgálatát”. A gyakorlás révén szerzett tudás ugyanis elfedheti a képességet, illetve a képesség hiányát. Hermann egyetért Révész Gézával, aki szerint a tesztvizsgálat sematikus, az intelligenciának csak bizonyos oldalaira vet fényt és csak tömegvizsgálatokat elégít ki; sem egyéni képességek mérésére, sem a tehetségek vizsgálatára nem alkalmas. A feladathelyzet ugyanis nem kedvez a spontaneitásnak - írja le Hermann. Összességében arra az álláspontra helyezkedik, hogy a tesztek csak felületes „tüneti” jellegzetességeket képesek bemutatni, amelyek csupán egy-egy elkülönült képességre nézve mérvadóak (Hermann, 1919. 191. o.).

Boda István, az 1928-ban útjára induló Magyar Pszichológiai Szemle főszerkesztője szintén szkeptikus az intelligencia univerzális jellegével kapcsolatban. Az ő meghatározása szerint az értelmesség különböző képességek szervezett rendszere, amelyben vannak általános - lényeglátás, kritikai képesség; speciális - logikai, oki gondolkodás -, és formai képességek, mint a gyorsaság és az elevenség. Emellett azonban - hívja fel Boda a figyelmet - a teljesítményeket befolyásolják az érdeklődés és az érzelmek is. 1931-ben megjelent írásából szó szerint idézünk: „Bizonyára nem véletlen, hogy eddig nem mutatta ki senki, hogy az intelligencia fogalmába pontosan ezek és ezek az értelmi értékek tartoznak bele.Voltaképen az, amit intelligencia szóval ártalában érteni szoktunk, nem is minden történeti korban, nem minden emberfajnál és népnél, nem minden éghajlat alatt, nem minden társadalmi osztály tagjai számára és nem minden körülmények között stb. stb. ugyanaz az egy, egyszer s mindenkorra pontosan megállapítható azonos összetevőkkel és pontosan ugyanazon összetevődési, organizációs viszonyokkal bíró valami. Az általánosan intelligensnek mondott angol bizonyára nem pontosan ugyanazon jellegú és összetevődöttségú intelligencia által ítéltetik intelligensnek, mint például az otthonában intelligensnek tartott hindu, vagy az intelligensnek tartott kínai; a középkori intelligens ember bizonyára nem ugyanazon tényezők birtokában vált intelligenssé, mint a huszadik században intelligensnek tekintett ember; de csak a közép és felső osztályok intelligenciája is összetevőiben is más, semmint az alsó osztályoké, az iparosé is voltakép más, mint a földmúveloé és más, mint a kereskedoé, a 
kereskedő viszont más lelki tényezőknél fogva tartatik intelligensnek, semmint a tudós stb... hiszen pl. még a gyakorlatban jól bevált Binet - Simon gyermeki intelligenciavizsgálati rendszer is a különféle fajú és nemzetiségú gyermekek sajátos intelligenciájánnak megfelelően országonként való módosításokra kényszerült (és e módosítási kényszer nem magyarázható egyedül csak a más-más nemzetbeli gyermekek fejlődési különbségeivel)." (Boda, 1931. 29. o.).

A hazai pszichológia fiatal tehetsége, Harkai Schiller Pál is komplexebbnek véli az értelem múködését, mint amit egy teljesítmények értékelésén alapuló adatsor tükrözhet. A Magyar Államvasutak pszichotechnikai laboratóriumában és a honvédség Képességvizsgáló Intézetében több mint ezer érettségizett fiatalembert vizsgáltak pályaalkalmasság szempontjából. A feladatokat maga H. Schiller állította össze más tesztekből. Segítségükkel a megfigyelést, a lényeglátást, a matematikai intelligenciát és a logikus következtetés képességét vizsgálták. Az értelemvizsgálatok mellett „cselekvéspróbát” is alkalmaztak, amely feltevésük szerint a jellembeli sajátosságok megismerését szolgálta. $\mathrm{H}$. Schiller azt is megállapítja, hogy a teszteredmények függetlenek az érettségin való bukástól: a bukottak között ugyanannyian voltak a jól teljesítők, mint a teszt alapján gyengébb értelmúek. Azok, akik jeles vagy jó eredményt értek el az érettségin, magas pontszámot értek el a tesztvizsgálatokban is, összességükben azonban a teszteredmények csak mintegy 16\%-ban mutattak egyezést az érettségi eredményével. Mindebből Harkai Schiller arra a következtetésre jut, hogy az érettségi bizonyítvány eredménye nem tükrözi a gyakorlatban is alkalmazható képességek színvonalát: a megfigyelőképességet és a józan értelmet, vagyis a pszichológiai értelemben vett intelligenciát. Úgy véli, hogy a „szabadon osztályozott teljesítménybecslés" megbízhatóbb, mint a statisztika és Németországban is egyre inkább ezt alkalmazzák a pontozással szemben. Fontosnak tartja, hogy a vizsgálómódszerek segítségével következtetni lehessen az érzelmi, akarati tulajdonságokra is (Harkai Schiller, 1935. 432. o.).

Egy másik, Komjáthy Zoltánnal írt tanulmányában alacsony iskolázottságú sorkatonák vizsgálatáról számol be. Felfigyelnek rá, hogy a vizsgált személyek nem egyszerúen nem találnak rá a helyes megoldásra, hanem másfajta gondolkodásés következtetésmód jellemzi őket. A jelenséget példák sokaságával világítják meg: amikor egy fogalom felsőfogalmát kellett megadni, a megkérdezettek a „,tarisznyát” a ruhák, a „hízót" az ételek, a „,borjúsültet” pedig állatok kategóriájába sorolták, amikor pedig a „kés, villa, fưrész, kasza” csoportból a nem odaillőt kellett volna megjelölni, a jellegzetes válasz a „kasza” volt a „villa” helyett. A matematikai jellegú feladatban a 20 és a 60, illetve a 30 és a 70 közé eső számokat kellett kiválasztani egy 12 tagú számsorból. Ebben az esetben jóval többször hibáztak a második esetben, holott logikai szempontból semmilyen különbség nincs a két intervallum között. Annak sincsen egyértelmú racionális magyarázata, miért bizonyult könnyebbnek a vizsgált személyek számára egy számsorból a 4-el osztható számok megtalálása, mint a 3-al oszthatóké. Harkaiék 
következtetése szerint az „iskolázatlan logika” nem azonos a „relációs logiká”val. A vizsgálatban résztvevő, pallérozatlan gondolkodású személyek az együtt tapasztalt, érintkező, vagy egymásból származó dolgokat tartották egy osztályba tartozónak- állapítják meg. A képességmérés azonban torz eredményekre fog vezetni, ha a vizsgálók nem veszik figyelembe a gondolkodásbeli különbségeket. A vizsgálati szempontokat a vizsgálandóktól kell tanulni - hívják fel a figyelmet a szerzők. A képességmérésnél nem elegendő a sztenderdizálás, hanem szükség van az előzetes kipróbálásra, más tesztekkel való összehasonlításra, a tipikus hibák kiszúrésére - ezt a folyamatot a szerzők kalibrálásnak nevezik. A képességmérésnek nem elvont normákhoz, hanem az emberi természethez kell alkalmazkodnia - összegzik a tapasztalataikat (Komjáthy és Harkai Schiller, 1938).

A képességek autentikus vizsgálatának problémája áll Baranyai Erzsébet érdeklődésének középpontjában is - ő a kevesek egyike, aki a világháború után is Magyarországon marad és 1960-ban részt vesz az Éltes-Binet-teszt korszerúsítésében (Czeizel és mtsai, 1978). 1929-ben beszámol amerikai tapasztalatairól a képességméréssel kapcsolatban. „A gyermek értelmi állapotának felmérése ma láz Amerikában” - írja a Széphalom címú folyóiratban. „Megmérnek minden funkciót, megmérnek mindent, ami megmérhető és meg nem mérhető, azaz, hogy ilyen nincs is az amerikai szerint, mert ami létezik, az kvantitásban létezik". Az intelligencia mértéke pontokban fejeződik ki, az idiótától a géniuszig - országos felzúdulást váltott ki, hogy megmérték egy egyetem hallgatóinak intelligenciáját, és az meglepően alacsonynak bizonyult. Ám az Egyesült Államokban vezéreszme, hogy minden korrigálható - tudósít. Az iskolákban vannak „orvosló kurzusok, orvosló számtan és orvosló olvasás”, a pszichológia osztályon a gyermek magatartását orvosolják. Baranyainak imponál, hogy fontosak a tanórán kívüli foglalkozások, a sport, a múvészetek, valamint, hogy a középiskola ingyenes és a gyerekek 33\%-a be is iratkozik - ez abban az időben igen magas aránynak számít. De kurzusokra járnak a felnőttek, sőt az idősek is (Baranyai, 1929. 324. о.).

Ő azonban nem elégedett az intelligencia tesztekkel végzett vizsgálatával, a tartalmi különbségeinek fontosságára, a gondolkodás, értelmi képességek egyedi voltára hívja fel a figyelmet a Magyar Pszichológiai Szemlében megjelent írásában (Baranyai, 1938). Kifogásolja, hogy az értelmi képességeket "szkémákhoz" igyekeznek hasonlítani, holott az mindenkinél más formát ölt. A „magasabb rendú értelmesség", az alkotóképesség egyáltalán nem vizsgálható statisztikai eszközökkel, a gondolkodás folyamata legalább olyan fontos, mint az eredményszögezi le, kiemelve, hogy a gondolkodást az érzések is alakítják, és az érzéseket is magában foglaló gondolkodás az igazán magas szintú gondolkodás. Egy másik tanulmányában (Baranyai, 1939) kritikai éllel ismerteti a Binet-tesztet. Az értelmesség nem egyértelmú dolog - szögezi le. A magasabb rendú értelmesség egynemú, affektív szinezetú, egyéni sajátosságokat hordozó szellemi erő, amely „objektív gondolati tartalomhoz illeszkedve új és átfogó gondolati struktúrát 
alkot" (Baranyai, 1939. 12. o.). Ez a tulajdonság tesztekkel nehezen vizsgálható, mert minőségi és nem mennyiségi - állapítja meg. A vizsgálatára különböző módszerek léteznek, mint például hiányos mondatok kiegészítése, értelmetlen szóhalmazok mondattá formálása, abszurd ítéletek helyességének, vagy helytelenségének megítélése. Ő maga is végez ilyen kísérletet: az általa vizsgált gyerekeknek történeteket kellett befejeznie. Az egyik ilyen történetben egy gyerek gyönyörú játékot kapott ajándékba, de nem játszik vele; egy másikban biciklit ajándékoztak neki a szülei, anyja aggódik miatta, apja nem. A válaszokat minőségi szempontok alapján igyekeztek értékelni, a jellegzetes választípusok megalkotásával.

Somos Gyula 1938-ban már egyenesen elavultnak véli a Binet-Simon-tesztet. Álláspontja szerint gyökeresen különbözik a gyermek és a felnőtt gondolkodásmódja, ezért az intelligenciájuk mérésének is más módszerekkel kellene történnie (Somos, 1938.).

Az értelmességgel kapcsolatos diskurzusba beszúrődnek a vesztes háború és a területveszteség okozta elkeseredettséget tükröző hangok is. Ballai Károly (1929) szerint a magyar gyermekek minden más gyermektől különböző tulajdonságokkal rendelkeznek, és ezt egyebek között azzal támasztja alá, hogy Éltes a Binet-teszt adaptációja során különbségeket talált a francia és a magyar gyermekek teljesítménye között. Véleménye szerint a magyar gyermekeket, akár a felnőtteket, igen erős „faji, hazafias érzés” jellemzi. A magyar gyermek elsősorban a történelmet szereti, „mert abban fajtája hősi küzdelmeiről olvas, a nemzet fenntartó harcait ismeri meg. A józan gondolkodás gyökereit is megtaláljuk", míg az anyagi érdeklődés kevésbé jellemzi a magyar gyermeket. (Ballai, 1929. 80. o.) „Akaratmúködésében feltúnő a harc, a küzdelem iránti hajlandóság. Ezen a téren, akár a felnőtt, elszánt és határozott”" (Ballai, 1929. 82. o.).

\section{EPILÓGUS}

A közeledő második világháború, a szakemberek kivándorlása, a szakmai körök felbomlása véget vet az értelmi képességek mérhetőségével kapcsolatos töprengéseknek és vitáknak. A baloldali diktatúrában az intelligenciamérés bírálatának politikai színezete lett, amely része volt a pszichológia elutasításának. Később, az enyhülés idején, az 1960-as évektől a hazai pszichológusok is egyre szélesebb körben alkalmazták a mindenkori képességmérések alapját jelentő IQ teszteket, immár kétségek és kritikai hangok nélkül.

\section{FELHASZNÁLT IRODALOM}

Ballai Károly (1929): A magyar gyermek. Magyar Gyermektanulmányi Társaság, Budapest.

Baranyai Erzsébet (1929): Amerikai nevelés. Széphalom, 3. 9-10 sz. o.n.. 
Baranyai Erzsébet (1938): A magasabbrendú értelmesség meghatározása és vizsgálatának módszere. Acta Litterarum ac Scientiarum Reg. Universitatis Hung Francisci-Iosephinae, Szeged.

Baranyai Erzsébet (1939): Értelmesség és egyéniség. Magyar Pszichológiai Szemle, 12. 1-4. sz. 22-29.

Binet, A. (1900): La Suggestibilité. Scheicher, Paris.

Binet, A. (1916): Az iskolásgyermek lélektana. Magyar Gyermektanulmányi Társaság, Budapest.

Berkovits René (1913): A gyermeki intelligencia vizsgálata. A gyermek, 7. 6. sz. 393-410.

Boda István (1931): A következtető képesség, mint értelmiségvizsgálati probléma. Magyar Pszichológiai Szemle, 4. 1-2. sz. 26-79.

Czeizel Endre, Lányiné Engelmayer Ágnes és Rátay Csaba (1978, szerk.). Az értelmi fogyatékosságok kóreredete a „Budapest vizsgálat” tükrében. Medicina Kiadó, Budapest.

Csillag Lipót (1918): Helyes-e a gyermekeket intelligenciájuk szerint elkülönítve külön osztályokban tanítani? Nemzeti Kultúra, 4. 1-2. sz. 2-3.

Deák Gábor (2000): A magyar gyermektanulmányi mozgalom története. Fővárosi Pedagógiai Intézet, Magyar Pedagógiai Társaság, OPKM, Budapest.

Donner Lajos (1899:) A gyermek értelmi fejlődése gyermekpsychologiai szempontból. Corvina, Békéscsaba.

Éltes (Ellenbach) Mátyás (1902): A gyengeelméjüek világából. Neuwald Kiadó, Budapest.

Éltes Mátyás (1914a): A Binet-Simon féle intelligenciavizsgálat eredménye magyar gyermekeken. A Gyermek, 8. 4. sz. 257-274.

Éltes Mátyás (1914b): A gyermeki intelligencia vizsgálata. Atheneum, Budapest.

Éltes Mátyás (1915): Hol kellene hazánkban kisegítő iskolákat állítani? A Gyermek, 9. 3-4. sz. 107-112.

Éltes Mátyás (1928): Iskolák szekunda nélkül. Magyar Gyógyedagógus, 16. 4-6 79-82.

Eperjessy István (1906): A népiskolába lépő gyerekek ismeretvilága. Népmüvelés, 2. 7-12 125-135.

Focher László és Szondi Lipót (1919): A szellemi képességek korellációi gyermekeken és kismúveltségú felnőtt egyéneken. A Gyermek, 13. 2. sz. 199-209.

Gál Anikó (2012): A gyermektanulmányozás és a gyógypedagógia kapcsolata Magyarországon a 20. század első felében. 62. 11-12. sz. 224-234. online: http://epa.oszk.hu/00000/00035/00155/pdf/EPA00035_upsz_2012_ 11-12_224-234.pdf megtekintés: 2016.09.01.

Gordosné Szabó Anna (1991): Éltes Mátyás: egy követésre méltó életút. Gyógypedagógiai Szemle, 19. 4. sz. 282-287.

Gould, S. J. (1999): Az elméricskélt ember. Typotex, Budapest. 
Harkai Schiller Pál (1935): Érettségizettek értelemvizsgálata. Magyar Pszichológiai Szemle 8. 3-4. sz. 425-435.

Hermann Imre (1919): A tesztvizsgálat módszertani elvei. A Gyermek, 13. 2. sz. 188-198.

Komjáthy Zoltán és Harkai Schiller Pál (1938): Értelempróbák szerkesztése. Magyar Pszichológiai Szemle, 11. 1-4. sz. 141-157.

Kun Miklós és Szegedi, Márton (1978, szerk): Az intelligencia mérése. Medicina, Budapest.

Mészáros István, Németh András és Pukánszky Béla (1999): Bevezetés a pedagógia és az iskoláztatás történetébe. Osiris Kiadó, Budapest.

Nagy László (1906): A gyermektanulmányozás mai állapota. A Magyar Filozófiai Társaság közleményei, 6. 2. sz 57-90., 3. sz. 143-151.

Nagy László (1912): Iskolás gyermekek értelmességének vizsgálata. (könyvismetetés) A Gyermek, 6. 2. sz. 89-91.

Nagy László (1926): Beszámoló a gyermeki egyéniség vizsgálati módszereiről. A Gyermek, 96-104.

Pethes János (1901): Gyermekpsychológia. Lampel Kiadó, Budapest.

Pléh Csaba (2000): A lélektan története. Osiris Kiadó, Budapest.

Pléh, Csaba (2004): Magyar hozzájárulások a modern pszichológiához. In: Pléh Csaba és Boross Ottília (szerk.): Bevezetés a pszichológiába. Budapest, Osiris Kiadó.

Pléh, Csaba (2009): Révész Géza - a sors feszültségei levelezése és székfoglalója tükrében. Thalassa, 20. 4. sz. 75-100.

Pukánszky Béla (2001): Felméri Lajos ismeretlen arca - a gyermekkép újszerú vonásai az első kolozsvári pedagógiaprofesszor írásaiban. In: Csapó Benő és Vidákovich Tibor (szerk.): Neveléstudomány az ezredfordulón. Nemzeti Tankönyvkiadó, Budapest. 423-432.

Somos Lajos (1938): Az intelligencia (értelmesség) és nevelése mai megvilágításban. Néptanítók lapja, 71. 14. sz. 568-571.

Szabolcs Éva (2002): A gyermektanulmányi szemlélet megjelenése a magyar pedagógiai sajtóban 1890-1906. Iskolakultúra, 12. 3. sz. 33-38.

Vajda Zsuzsanna (1995): A pszichoanalízis budapesti iskolája és a nevelés. Sík Kiadó, Budapest.

Vajda Zsuzsanna (2017): Hosszú haj, rövid ész? Férfiak és nők értelmi képességei a legújabb kutatások tükrében. Magyar Tudomány, 178. 3. sz. 322-336. 